\title{
Analisis EVA, MVA, dan Tobin's Q Terhadap Harga Saham Emiten di BEI Periode 2012-2016
}

\author{
Stevi Jimry Poluan, Rony Joyo Negoro Octavianus, Edwin Aditya Prabowo \\ email: stevi.jimry@machung.ac.id \\ Universitas Ma Chung Malang
}

\begin{abstract}
This study aims to analyze the effect of EVA, MVA, and Tobin's $Q$ on share price of listed companies in IDX. The type of research used on this study is assosiative research with quantitative approach. Sampling method used is purposive sampling. Multiple Linear Regression used to analyze the data. The results showed that EVA had no effect to companies' stock prices and MVA had positive and significant effect to companies' stock prices, and Tobin's $q$ had positive and significant effect to companies'stock prices.
\end{abstract}

Keywords: EVA, MVA, Tobin's Q

\section{PENDAHULUAN}

Perekonomian negara-negara saat ini di pengaruh oleh bursa efek atau pasar modal. Peran bursa efek memilik pengaruh yang besar pada ekonomi negaranegara maju dan berkembang, karena memiliki peran dalam fungsi keuangan dan fungsi ekonomi. Ang (1997) mengatakan pasar modal bisa menjadi indikator berkembangnya perekonomian suatu negara serta dapat menunjang ekonomi negara tersebut. Dimana bursa efek dapat dijadikan sarana untuk jual beli saham dan tempat untuk mencari pendanaan bagi perusahaan-perusahan atau emiten yang terdaftar di bursa efek tersebut, karena bursa efek berfungsi juga sebagai pasar modal bagi investor-investor yang mencari pendanaan dan investor yang memberikan pinjaman atau sering disebut tempat pertemuan antara debitur dan kreditur. Saat ini saham juga dijadikan sebagai instrumen keuangan di padar modal Indonesia karena dapat mendorong perkembangannya pasar modal Indonesia, hal ini terbutkti dengan meningkatnya volume perdagangan saham di bursa efek. 
Hendrata (2001) mengatakan para calon investor (kreditur dan debitur) menjadikan rasio keuangan sebagai tolak ukur dalam berinvestasi. Jika rsio keuangan perusahaan dalam keadaan tidak bagus, investor lebih cenderung untuk tidak melakukan investasi, tetapi pada saat rasio keuangan dalam keadaan bagus, investor tersebut akan menginvestasikan modalnya pada perusahaan yang tersebut. Menggunakan rasio keuangan sebagai acuan para investor dalam berinvestasi yaitu dengan melihat kenerja perusahaan tesebut, dimana kinerja perusahaan dapat dilihat dari historikal nilai keuangannya, dan seorang investor dapat melakukannya tanpa harus mempetimbangkan nilai pasar dari aset perusahaan tersebut.

Posisi laporan keuangan dapat dijadikan sebagai acuan untuk melihat kinerja perusahaan bagi para investor, masalah ini begitu penting bagi mereka. Karena digunakan untuk melihat aatau mengetahui keunggulan dan kelemahan perusahaannya. Keunggulan diperlu diketahui oleh para investor dalam berinvestasi karena mereka dapat memikirkan apakah dapat mempertahan investasi dan menambah jumalah investasinya pada perusahaan tesebut begitu juga sebaliknya dengan kelemahan. Kinerja keuangan suatu perusahaan dapat dinilai dengan menggunakan beberapa alat analisis keuangan, salah satunya yaitu laporan keuangan dengan menggunakan pendekatan beberapa rasio keuangan, dalam Andika (2016).

Pengukuran kinerja perusahaan berkaitan dengan harga sahamnya, jika kinerja perusahaan tersebut bagus maka harga saham perusahaan tersebut juga akan meningkat. Perusahaan yang mampu menambah nilai perusahaan mereka, maka kinerja perusahaan akan menjadi baik karena perusahaan mampu menghasilkan nilai tambah ekonomis bagi pemegang saham dan investor. Hal tersebut menunjukan juga bahwa kinerja keuangan yang dilakukan sudah efektif dan efisien, dimana manajemen perusahaan mampu mengelola keuangan dengan baik. (Iswandari, dkk. (2015)). 
Pada saat investor menilai perusahaan penerbit saham dalam kondisi baik, biasanya harga saham perusahaan yang bersangkutan akan naik, sedangkan jika perusahaan dinilai rendah oleh pasar, harga saham perusahaan juga akan ikut turun bahkan bisa lebih rendah dari harga di pasar sekunder antara investor yang satu dengan investor yang lain sangat menentukan harga saham perusahaan, (Andika, 2016) dan (R, Bergitta Sonia.dkk, (2014). Hal ini terjadi karena return saham yang di harapakan oleh para investor pada perusahaan tesebut dapat tercapai. Samsul, (2006) mengatakan return saham adalah pendapatan yang dinyatakan dalam presentase dari modal awal investasi (Samsul, 2006:291).

Pendapatan investasi ini merupakan sebuah keuntungan dari jual beli saham. Keuntungan yang timbul atas perdagangan saham ialah deviden saham yang terdiri dari deviden kas dan deviden non kas serta Capital Gain. Sedangkan harga saham adalah nilai-nilai yang terkandung dalam saham menurut Horne dan Wachowics (2007:373-375) dapat dibedakan dalam empat golongan, yaitu nilai dasar (Base Price), nilai nominal (Par Value), nilai buku (Book Value), dan nilai pasar (Market Price). Faktor-faktor yang mempengaruhi harga saham adalah kondisi fundamental emiten, hukum permintaan dan penawaran, tingkat suku bunga, valuta asing, dana asing di bursa, indeks harga saham, serta news dan rumors. Economic Value added (EVA), Market Value Added (MVA) dan Tobin's Q merupakan bagian dalam mengukur kinerja perusahaan, beberapa penelitian sebelumnya juga menunjukkan adanya pengaruh kinerja perusahan terhadap harga saham, karena kinerja perusahaan menjadi lebih baik, Syahirah dan Lantania (2016), Kusuma dan Topowijoyo (2018), Hermuningsih (2018) dan Sudiyatno (2010).

\section{Economic Value Added (EVA)}

Economic Value Added menurut Brigham \& Houstan (2009), adalah nilai yang ditambahkan oleh manajemen kepada pemegang saham selama satu tahun tertentu. EVA mencerminkan laba residu yang tersisa setelah biaya dari seluruh modal termasuk modal ekuitas dikurangkan. Hal ini senada dengan pendapat 
Endri (2005) yang mendefinisikan EVA sebagai sisa laba (residual income) setelah semua penyedia kapital diberi kompensasi yang sesuai dengan tingkat pengembalian yang dibutuhkan atau setelah semua biaya kapital yang digunakan untuk menghasilkan laba tersebut dibebankan. Menurut Warsono (2003), EVA adalah perbedaan antara laba operasi setelah dengan biaya modalnya. Economic Value positif mengindikasikan perusahaan berhasil menciptakan nilai bagi pemilik perusahaan, dengan tujuan memaksimalkan nilai perusahaan. Economic Value (EVA) berfokus pada efektivitas manajerial pada tahun tertentu dengan memperkirakan keuntungan ekonomi yang diperoleh.

Kelebihan EVA adalah mampu menggambarkan kondisi keuangan perusahaan secara lebih baik, karena EVA tidak hanya mempertimbangkan biaya utang, tetapi juga biaya ekuitas (Simbolon, et al., 2014). Brigham dan Houston (2010:111) mendefinisikan EVA sebagai “estimasi laba ekonomi usaha yang sebenarnya untuk tahun tertentu”. EVA menunjukkan sisa laba setelah biaya modal. Perusahaan yang memiliki EVA tinggi cenderung dapat lebih menarik investor untuk berinvestasi di perusahaan tersebut, karena semakin tinggi EVA maka semakin tinggi pula nilai perusahaan. Menurut Mederios (2005), hubungan antara EVA dan harga saham akan semakin mudah dimengerti apabila ada variabel lain yang digunakan untuk mengukur kinerja perusahaan. Hal ini disebabkan karena EVA perusahaan memiliki pengaruh terhadap nilai pasar perusahaan, sehingga seharusnya nilai pasar perusahaan bernilai lebih besar dibandingkan dengan modal yang diinvestasikan.

\section{Market Value Added (MVA)}

Market Value Added (MVA) merupakan perbedaan antara nilai modal yang ditanamkan di perusahaan sepanjang waktu dari investasi modal, pinjaman, laba ditahan, dan uang yang bisa diambil sekarang atau sama dengan selisih antara nilai buku dengan nilai pasar perusahaan (Rahayu, 2007). Perusahaan dikatakan berhasil menciptakan nilai tambah bagi pemilik modal, jika EVA dan MVA bernilai positif, karena perusahaan mampu menghasilkan tingkat pengembalian 
yang melebihi tingkat biaya modal (cost of capital) diikuti dengan meningkatnya harga saham. Namun, jika EVA dan MVA bernilai negatif, hal ini menunjukkan nilai perusahaan menurun yang diikuti dengan penurunan harga saham, karena tingkat pengembalian lebih rendah dari biaya.

Brigham \& Houston (2010) juga menjelaskan bahwa MVA adalah “perbedaan antara nilai pasar ekuitas suatu perusahaan dengan nilai buku seperti yang disajikan dalam neraca, nilai pasar dihitung dengan mengalikan harga saham dengan jumlah saham yang beredar”. Sedangkan Manurung (2007) menjelaskan MVA adalah "perbedaan antara nilai pasar dari perusahaan (hutang dan ekuitas) dengan total modal yang diinvestasikan ke dalam perusahaan”. MVA yang tinggi menunjukkan kinerja manajemen perusahaan yang baik (Simbolon, et al., 2014). Dengan kata lain MVA yang tinggi menunjukkan kinerja perusahaan yang baik juga, sehingga dapat mempengaruhi harga saham perusahaan.

\section{Tobin's Q}

Tobin's $q$ adalah indikator untuk mengukur kinerja perusahaan, khususnya tentang nilai perusahaan, yang menunjukkan suatu proforma manajemen dalam mengelola aktiva perusahaan. Nilai Tobin's $q$ menggambarkan suatu kondisi peluang investasi yang dimiliki perusahaan (Lang, et al 1989) atau potensi pertumbuhan perusahaan (Tobin \& Brainard, 1968; Tobin, 1969). Nilai Tobin'q dihasilkan dari penjumlahan nilai pasar saham (market value of all outstanding stock) dan nilai pasar hutang (market value of all debt) dibandingkan dengan nilai seluruh modal yang ditempatkan dalam aktiva produksi (replacement value of all production capacity), maka Tobin's q dapat digunakan untuk mengukur kinerja perusahaan, yaitu dari sisi potensi nilai pasar suatu perusahaan.

\section{Harga Saham}

Sartono (2008:9) menyatakan bahwa harga saham terbentuk dipasar modal dan ditentukan oleh beberapa faktor seperti laba per lembar saham atau earning per share, rasio laba terhadap harga per lembar saham atau price earning ratio, 
tingkat bunga bebas resiko yang diukur dari tingkat bunga deposito pemerintah dan tingkat kepastian operasi perusahaan. Return saham adalah pendapatan yang dinyatakan dalam presentase dari modal awal investasi (Samsul, 2006:291). Pendapatan investasi ini merupakan sebuah keuntungan dari jual beli saham. Keuntungan yang timbul atas perdagangan saham ialah deviden saham yang terdiri dari deviden kas dan deviden non kas serta Capital Gain.

\section{Hubungan Antara EVA dengan Harga Saham}

EVA menggambarkan keuntungan ekonomi yang didapatkan oleh perusahaan. EVA yang tinggi akan meningkatkan harga saham perusahaan karena perusahaan telah berhasil menciptakan kekayaan bagi para pemegan sahamnya sehingga nilai saham perusahaan tersebut meningkat (Sunardi, 2012). Dalam pengukuran EVA, nilai EVA berada di bawah nol menandakan perusahaan tidak mampu menciptakan keuntungan ekonomis dan gagal memenuhi harapan investor sehingga harga saham perusahaan akan mengalami penurunan (Rahayu \& Dana, 2016). Hal ini sesuai dengan penelitian-penelitian terdahulu yang dilakukan oleh Riska, Sukamonto, \& Nurhayati (2015), Ikbar dan Dewi (2013), Hidayat (2016), dan Panahi, Preece, Zakaria, \& Rogers (2014) yang menemukan EVA berpengaruh positif terhadap harga saham.

\section{Hubungan Antara MVA dan Harga Saham}

MVA adalah pemaksimalan kenaikan nilai pasar dari modal perusahaan di atas modal yang disetor pemegang saham (Gulo \& Ermawati, 2011). Kenaikan MVA menandakan nilai pasar harga saham perusahaan menigkat sehingga harga saham perusahaan meningkat. MVA yang bernilai negatif menunjukkan penurunan nilai perusahaaan. Turunnya nilai perusahaan akan diikuti oleh turunnya harga saham (Rahayu \& Dana, 2016).

Hal ini sesuai dengan hasil dari penelitian - penelitian terdahulu. Penelitian yang dilakukan oleh Puspita, Isnurhadi, \& Umrie (2015), Rahayu \& Dana (2016), Ikbar dan Dewi (2013), Panahi, Preece, Zakaria, \& Rogers (2014), Rahayu dan 
Dana (2016), Nugroho (2016), dan Sonia R, Zahroh, \& Azizah (2014) menemukan MVA berpengaruh positif terhadap harga saham.

\section{Hubungan Tobin's Q dengan Harga Saham}

Secara sederhana, Tobin's $q$ adalah pengukur kinerja dengan membandingkan dua penilaian dari asset yang sama. Tobin's $q$ merupakan rasio dari nilai pasar asset perusahaan yang diukur oleh nilai pasar dari jumlah saham yang beredar dan hutang (enterprise value) terhadap replacement cost dari aktiva perusahaan (Fiakas, 2005). Apabila perusahaan memiliki nilai lebih besar dari nilai dasar sebelumnya, maka akan memiliki biaya untuk meningkatkan kembali, dan laba kemungkinan akan didapatkan. Berdasarkan pemikiran Tobin, bahwa insentif untuk membuat modal investasi baru adalah tinggi ketika surat berharga (saham) memberikan keuntungan di masa depan dapat dijual dengan harga yang lebih tinggi dari biaya investasinya (Fiakas, 2005).

Hasil dari penelitian-penelitan yang sudah dilakukan sebelumnya memiliki hasil yang beragam. Penelitian yang dilakukan oleh Riska, et.al (2015), menemukan bahwa EVA berpengaruh positif terhadap harga saham, sedangkan hasil penelitian Rahayu dan Dana (2016) menunjukkan EVA berpengaruh negatif terhadap harga saham. Penelitian Mugi, et.al (2014) menemukan tidak adanya pengaruh EVA terhadap harga saham. Penelitian yang dilakukan Puspita, et.al (2015) menemukan MVA memiliki pengaruh positif terhadap harga saham, berbeda dengan penelitian yang dilakukan oleh Hidayat (2016) yang menemukan MVA berpengaruh negatif terhadap harga saham.

Penelitian ini diharapkan dapat membantu para investor dalam mengambil keputusan berinvestasi dengan menilai kinerja perusahaan terhadap harga saham. Selain itu, penelitian ini diharapkan mampu memberikan gambaran mengenai kinerja perusahaan-perusahaan yang terdaftar di BEI dan dampaknya tderhadap harga saham. Perbedaan penelitian ini dengan penelitian sebelumnya terletak pada objek penelitian dan luas penelitian. Jika penelitian-penelitian terdahulu hanya menenliti EVA dan MVA pada satu sektor di BEI, penulis meneliti EVA, MVA 
dan Tobin's Q dengan menggunakan semua sektor yang ada di BEI terhadap harga saham.

\section{METODE PENELITIAN}

Penelitian ini adalah penelitian asosiatif dengan pendekatan kuantitatif. Penelitian asosisatif adalah penelitian yang bertujuan untuk mengetahui hubungan antar dua variabel atau lebih (Sugiyono, 2012). Data yang digunakan dalam penelitian ini adalah data sekunder berupa harga saham emiten yang diperoleh dari situs www.duniainvestasi.com dan laporan keuangan perusahaan yang diperoleh dari BEI melalui situs www.idx.co.id. Data penelitian ini dikumpulkan dengan menggunakan metode dokumentasi, yaitu metode pengumpulan data yang diperoleh secara langsung melalui media perantara (Indriantoro dan Supomo, 2002).

Populasi penelitian ini adalah seluruh perusahaan yang terdaftar di BEI periode 2012-2016. Pengambilan sampel dilakukan dengan metode purposive sampling dengan ketentuan:

1. Tercatat di BEI dan mempublikasikan laporan keuangan tahunan secara rutin pada periode 2012-2016.

2. Tidak mendapatkan suspense dari BEI selama periode 2012-2016.

3. Melakukan perdagangan saham selama periode 2012-2016

Berdasarkan kriteria tersebut maka di dapatkan jumlah sampel penelitian 302 perusahaan di BEI. Kemudian penelitian ini menggunakan empat variabel yang terdiri dari EVA, MVA, Tobin's Q dan Harga Saham. Perhitungan variabelvariabel tersebut adalah sebagai berikut:

EVA $=$ NOPAT $-($ WACC $x$ Capital $)$

Rumus 1. EVA

Sumber: (Brigham \& F.Houston, 2010) 
EVA adalah alat yang digunakan untuk mengukur tingkat profitabilitas tahun operasi suatu perusahaan secara nyata juga mengukur kinerja manajemen berdasarkan besar kecilnya (Brigham dan F.Houston, 2010).

MVA=(Nilai Pasar Sah am - Nilai Buku Sah am)xJumlah Sah am

Rumus 2. MVA

Sumber: (Brigham \& F.Houston, 2010)

Market Value Added (MVA) adalah perbedaan antara nilai pasar saham perusahaan dengan nilai buku saham perusahaan yang telah dikalikan dengan jumlah saham beredar (Brigham dan F.Houston, 2010).

$\mathrm{Q}$ ratio $=\underline{\text { Market Value of Equity }+ \text { Liabilities }}$

Total Asset

Tobin's $q$ merupakan rasio dari nilai pasar asset perusahaan yang diukur oleh nilai pasar dari jumlah saham yang beredar dan hutang (enterprise value) terhadap replacement cost dari aktiva perusahaan (Fiakas, 2005).

Harga saham adalah harga jual dari investor yang satu dengan investor yang lain yang terjadi setelah saham tersebut dicatatkan di bursa efek pada saat akhir tahun.

Analisis data yang digunakan dalam penelitian ini adalah regresi linier berganda dengan persamaan:

$Y=a+b 1 \operatorname{Ln} X 1+b 2 \operatorname{Ln} X 2+b 3 \operatorname{Ln} X 3+e$

Keterangan:

$\mathrm{Y}=$ Harga Saham

$\mathrm{A}=$ Konstanta

$\mathrm{X}=\mathrm{EVA}$

$\mathrm{X} 2=\mathrm{MVA}$

X3= Tobin's Q

b1,2,3 = Koefisien Regresi variabel X 1,2,3

$\mathrm{e}=$ error 


\section{Hasil Analisis Regresi Linier Berganda}

\section{Tabel 1}

\section{Hasil Analisis Regresi Berganda}

\begin{tabular}{|c|c|c|c|c|c|c|}
\hline \multicolumn{7}{|c|}{ Coefficients $^{a}$} \\
\hline \multirow{2}{*}{\multicolumn{2}{|c|}{ Model }} & \multicolumn{2}{|c|}{ Unstandardized Coefficients } & \multirow{2}{*}{$\begin{array}{c}\text { Standardized } \\
\text { Coefficients } \\
\text { Beta } \\
\end{array}$} & \multirow[t]{2}{*}{$\mathrm{t}$} & \multirow[t]{2}{*}{ Sig. } \\
\hline & & B & Std. Error & & & \\
\hline \multirow{4}{*}{1} & (Constant) & -4.239 & 1.744 & & -2.430 & .016 \\
\hline & EVA & .018 & .019 & .046 & .943 & .347 \\
\hline & MVA & .282 & .037 & .426 & 7.712 & .000 \\
\hline & Tobin's Q & 1.134 & .187 & .308 & 6.063 & .000 \\
\hline
\end{tabular}

a. Dependent Variable: Harga_Saham

Sumber: Data Diolah (2018)

Berdasarkan hasil uji regresi pada tabel 1, persamaan regresi penelitian ini adalah $Y=-4,239+0,18 X 1+0,282 X 2+1,134 X 3$

Dengan nilai Sig EVA 0,374 > 0.5 sehingga hipotesis yang mengatakan EVA berpengaruh terhadap harga saham ditolak. Nilai sig pada MVA lebih kecil dari 0,05, yaitu 0,00 dan koefisien betanya positif sehingga hipotesis yang mengatakan MVA berpengaruh positif terhadap harga saham diterima. Nilai sig pada Tobin's Q lebih kecil dari 0,05, yaitu 0,00 dan koefisien betanya positif sehingga hipotesis yang mengatakan Tobin's Q berpengaruh terhadap harga saham diterima.

\section{PEMBAHASAN}

Berdasarkan hasil pengujian hipotesis pertama, EVA tidak berpengaruh terhadap harga saham emiten periode 2012-2016 karena nilai sig EVA lebih besar dari 0,05 yaitu 0,347. Salah satu kelemahan dari EVA adalah ketergantungan EVA terhadap keyakinan bahwa pendekatan fundamental sangat diandalkan oleh investor dalam melakukan investasi (Mirza, 1997). Bentuk efisiensi pasar modal 
BEI yang berbentuk lemah. Pada tingkat efisiensi pasar lemah, harga saham saat ini merefleksikan semua informasi yang tersedia pasar modal seperti data historis, tingkat pengembalian, volume perdagangan, dan informasi-informasi pasar modal lainnya (Brown dan Reilly, 2002). Hal ini ditunjukkan dari tingkat keuntungan investor dengan hanya menggunakan analisis teknikal sangat rendah, bahkan banyak investor yang mengalami kerugian (Ady dan Mulyaningtyas, 2017). Dalam bentuk pasar ini keputusan investasi hanya didasarkan pada data pasar modal, tanpa mempertimbangkan faktor-faktor fundamental.

Hasil pengujian MVA berpengaruh positif terhadap harga saham emiten periode 2012-2016. Hal ini didasari oleh hasil pengujian statistik yang menunjukkan signifikansi MVA lebih kecil dari 0,05, yaitu sebesar 0,00 dan nilai koefisien beta yang positif. Nilai MVA perusahaan yang tinggi menunjukkan kemampuan perusahaan dalam memberikan nilai tambah lebih bagi para pemegang sahamnya. Hal ini menyebabkan permintaan saham perusahaan meningkat, dengan persediaan saham yang tetap, menyebabkan naiknya harga saham perusahaan. Selain itu, MVA berpengaruh positif terhadap harga saham karena harga saham merupakan salah satu komponen di dalam rumus MVA.

Hasil pengujian Tobin’s Q berpengaruh positif terhadap harga saham emiten periode 2012-2016. Berdasarkan hasil pengujian statistik menunjukkan signifikansi Tobin's Q lebih kecil dari 0,05, yaitu sebesar 0,00 dan nilai koefisien beta yang positif. Tobin's Q sendiri mengandung harga saham sehingga apabila harga saham naik, maka nilai Tobin’s Q akan meningkat. Nilai Tobin’s Q yang tinggi juga menunjukkan kemampuan perusahaan mengelola aset, sehingga mampu memberikan sinyal positif bagi investor untuk melakukan investasi.

\section{KESIMPULAN DAN SARAN}

EVA tidak berpengaruh terhadap harga saham emiten periode 2012-2016 dan MVA dan Tobin's Q berpengaruh positif terhadap harga saham emiten periode 2012-2016. Hal ini disebabkan bentuk efisiensi pasar yang lemah dan 
mayoritas investor di BEI cenderung merupakan investor spekulan dan lebih menyukai keuntungan jangka pendek dan cenderung mengabaikan analisis fundamental.

Bagi investor sebaiknya tidak hanya mengandalkan analisis teknikal, melainkan mengandalkan analisis teknikal dan fundamental dalam mengambil keputusan investasi. Bagi perusahaan, sebaiknya melakukan corporate action untuk meningkatkan nilai perusahaan karena kecenderungan investor yang lebih menyukai keuntungan jangka pendek.

\section{DAFTAR PUSTAKA}

Ady, S. U., dan Mulyaningtyas, A. 2017. Eksplorasi Tingkat Efisiensi Pasar Modal Indonesia Studi Kasus Di Bursa Efek Indonesia. Ekspektra: Jurnal Bisnis dan Manajemen, Volume 1, Nomor 2, Hal 103-123.

Ang, Robert, 1997. Buku Pintar Pasar Modal Indonesia, Penerbit Mediasoft, Jakarta

Andika, Wifaqul Luthfa, 2016. Analisis Economic Value Added dan Market Value Added Sebagai Alat Pengukur Kinerja Perusahaan Serta Pengaruhnya Terhadap Harga Saham. Semarang: Universitas Negeri Semarang.

Bisnis Today. 2017. Program 'Yuk Nabung Saham Sukses Dongkrak Investor Baru Di Pasar Modal. Retrieved from Bisnis Today: http://bisnistoday.com/2017/02/04/program-yuk-nabung-saham-suksesdongkrak-investor-baru-di-pasar-modal/ [August 28, 2017].

Brainard, W, and Tobin, J, 1968. "Pitffals in Financial Model Building", American Economic Review, Vol. 58(2), pages 99-122.

Brigham, E. F., dan F.Houston, J. 2010. Dasar - Dasar Manajemen Keuangan Buku 1 (11 ed.). Jakarta: Salemba Empat. 
Brown, K. C., dan Reilly, F. K. 2002. Investment Analysis and Portfolio Management: 7th (Seventh) Edition. Ohio: South-Western/Thomson Learning.

Fiakas, D, 2005. Tobin’s Q: Valuing Small Capitalization Companies, Crystal Equity Research, April.

Gulo, W. A., dan Ermawati, W. J. 2011. Analisis Economic Value Added (EVA) dan Market Value Added (MVA) sebagai Alat Pengukur Kinerja Keuangan PT SA. Jurnal Manajemen dan Organisasi, Volume 2, No 2, Hal 123-133.

Hendrata. 2001. Analisis Economic Value Added (EVA) Dan Market Value Added (MVA) Sebagai Alat Pengukur Kinerja Perusahaan Serta Pengaruhnya Terhadap Harga Saham. Surabaya: Universitas Kristen Petra.

Hermuningsih, Sri. “Pengaruh EVA Terhadap Tobin’s Q Dengan MVA Sebagai Variabel Intervening”. EKOBIS Vol.19, No.1, Januari 2018.

Hidayat, A. M. 2016. Analisis Pengaruh Kinerja Perusahaan Dan Pasar Terhadap Harga Saham (Studi Kasus Pada Perusahaan Sub Sektor Makanan dan Minuman Periode 2011-2014). Jurnal Ilmiah Mahasiswa FEB Universitas Brawijaya, Vol 4, No.2.

Indriantoro, N., \& Supomo, B. 2002. Metode Penelitian Bisnis Untuk Akuntansi dan Manajemen. Yogyakarta: BPFE

Iswandari, dkk, (2015). Analisis EVA dan MVA Sebagai Alat Untuk Mengukur Kinerja Keuangan Perusahaan PT. Indofood Sukses Makmur Tbk. Jurnal Ilmiah Inovator, Edisi Maret 2015.

Kusuma, Ayu, Rizka, dan Topowijoyo. "Pengaruh EVA dan MVA Terhadap Return Saham (Studi Pada Perusahaan Yang Terdaftar Dalam Indeks LQ45 di BEI Periode 2012-2016)”. Jurnal Administrasi Bisnis (JAB)|Vol. 61 No. 3 Agustus 2018| 
Lang, L.H.P., Stulz, R.M, and Walkling, 1989. “Managerial Performance, Tobin’s q, and the Gains from Successful Tender Offers”. Journal of Financial Economics (September), 137-154.

Lang, L.H.P, and Stulz, R.M, 1994. “Tobin’s q Corporate Diversivication, and Firm Performance”. Journal of Political Economy, 102, 1248-1280.

Medeiros, O. R. 2005. Empirical Evidence on the Relationship Between EVA and Stock Returns in Brazilian Firms. University of Brasilia.

Mirza, T. 1997. EVA Sebagai Alat Penilai. Manajemen Usahawan Indonesia, Volume 4.

Mugi, A., Irwanto, A. K., dan Permanasari, Y. 2014. Analisis Pengaruh Rasio Profitabilitas dan Economic Value Added terhadap Harga Saham pada Sub Sektor Industri Semen yang Terdaftar di Bursa Efek Indonesia. Jurnal Manajemen dan Organisasi Vol 5, No 2, Hal 139-153.

Rahayu, N. M., dan Dana, I. M. 2016. Pengaruh EVA, MVA dan Likuiditas Terhadap Harga Saham Pada Perusahaan Food and Beverages. E-Jurnal Manajemen Unud, 5(1), 443-469.

R, Bergitta Sonia, ddk. “Analisis Pengaruh EVA, MVA, dan ROI Terhadap Harga Saham (Studi Pada Perusahaan Property dan Real Estate yang Terdaftar di BEI Periode 2009-2012)”. Jurnal Administrasi Bisnis (JAB)| Vol. 9 No. 1 April 2014.

Riska, Sukamarto, E., dan Nurhayati. 2015. Pengaruh Economic Added Value (EVA), dan Rasio Profitabilitas Terhadap Harga Saham. Prosiding Penelitian Sivitas Akademika Unisba (Sosial dan Humaniora), Hal 1-7.

Sartono, Agus. 2008. Manajemen Keuangan teori dan Aplikasi edisi 4. Yogyakarta: BPFE-YOGYAKARTA. 
Simbolon, R. F., Dzulkiron, M., dan Saifi, M. 2014. Analisis EVA (Economic Value Added) Untuk Menilai Kinerja Keuangan Perusahaan (Studi Kasus Pada Perusahaan Farmasi pada Bursa Efek Indonesia Periode 2010-2012). Jurnal Administrasi Bisnis (JAB), Vol.8, No 1, Hal 1-8

Sudiyatno, Bambang. “Tobin's Q dan ALTMAN Z-Score Sebagai Indikator Pengukur Kinerja Perusahaan”. Kajian Akuntansi, Februari 2010, Hal. 9 21 Vol. 2. No. 1 ISSN : 1979-4886

Sugiyono. 2012. Metode Penelitian Kuantitatif Kualitatif dan R\&D. Bandung: Alfabeta.

Syahirah, Sarah. Cut, Lantania, Febrianty, Maya. "Pengaruh MVA, EVA, Kebijakan Deviden dan Kepemilikan Manajerial Terhadap Nilai Perusahaan Pada Perusahaan Manufaktur Yang Terdaftar di BEI Tahun 2010-2014”. Jurnal Ilmiah Mahasiswa Ekonomi Akuntansi (JIMEKA) Vol. 1, No. 1, (2016).

Tobin’s, James, 1969. “A General Equilibrium Approach to Monetary Theory”, Journal of Money, Credit and Banking (February), 12-29. 